TRABAJO Y TRABAJADORES:

RED LATINOAMERICANA

\title{
Empresariado rural, modernização da agricultura e violência no meio rural brasileiro
}

\author{
LEONILDE SERVOLO DE MEDEIROS \\ Universidade Federal Rural do Rio de Janeiro \\ leonildemedeiros@gmail.com
}

\begin{abstract}
Resumo: $\mathrm{O}$ artigo analisa como o governo militar no Brasil, em suas políticas para o meio rural, atendeu algumas das principais demandas dos setores empresariais organizados em associações bastante ativas no período que antecede o golpe. Numa primeira parte, mostra como essas reivindicações se constituíram e os canais por onde elas eram tornadas públicas. Na sequência analisa a política do regime militar em relação ao campo, tanto na sua dimensão repressiva como na constituição de leis e de instituições que permitiram uma profunda transformação modernizadora da agricultura brasileira ao longo década de 1970. Na última sessão mostra como o desdobramento das políticas de modernização, as formas como seu deu a repressão e a continuidade da violência no campo trazem sensíveis obstáculos às possibilidades de políticas efetivas de uma justiça de transição.
\end{abstract}

Palabras clave: ditadura empresarial-militar, camponeses, empresariado rural, modernização agrícola, violência

Recebido: 28 de fevereiro de 2021 . Aprovado: 23 de abril de 2021 . 
No Brasil, ainda há muito a pesquisar sobre o que representou o golpe de 1964 para as áreas rurais, tanto no que se refere às formas de resistência camponesa ao longo da ditadura, quanto à ação empresarial e sua relação com processos de violação de direitos. ${ }^{1}$ De forma geral, a literatura explorou a modernização agrícola que ocorreu ao longo dos anos 1970, os seus desdobramentos no que diz respeito a um processo intenso e amplo de expropriação dos que viviam de seu trabalho e tinham alguma forma de acesso à terra, mas deu menos atenção às reivindicações e práticas dos segmentos empresariais, expressas por suas organizações de representação. ${ }^{2}$ Neste texto faço algumas reflexões sobre as demandas e práticas empresariais, utilizando a bibliografia corrente, parcelas de material de pesquisa feita no estado do Rio de Janeiro sobre conflitos e repressão no campo na ditadura militar, reflexões elaboradas ao longo das discussões possibilitadas pela minha participação na Comissão Camponesa da Verdade e em debates dela derivados. ${ }^{3}$ Aponto ainda algumas dificuldades que se antepõem à chegada da justiça de transição às áreas rurais. Mais do que afirmações consolidadas, trata-se de reflexões que mostram a importância de se aprofundar o tema em pesquisas futuras. Procuro mostrar continuidades e rupturas das questões relacionadas ao campo em três momentos da vida política brasileira: o que antecede o golpe, o da ditadura propriamente dita e o período imediatamente posterior, de redemocratização, no qual, todavia, onde há persistência de temas e práticas.

No período que antecede o golpe gestaram-se reivindicações e bandeiras, visibilizaram-se e foram submetidas à denúncia pública formas de repressão e exploração usuais no meio rural, jogando luzes sobre a violência endêmica que o marcaram desde o período colonial. Assim, inicio este artigo com uma

1 O texto retoma e atualiza reflexões e informações contidas no texto "O regime empresarial-militar e a questão agrária no Brasil”, em Jorge Ferreira, Lucília de Almeida Neves Delgado (org.), O Brasil Republicano, vol. 4. O tempo do regime autoritário. Ditadura militar e redemocratização. Quarta República (1964-1985) [9. ed.], (Rio de Janeiro: Civilização Brasileira, 2019). Também revisita o capitulo "Governos militares e trabalhadores do campo: Políticas públicas, modernização e mudança social”, publicado na coletânea organizada por Maria de Sousa Neves Martins; Pedro Henrique Pedreira Campos e Rafael Vaz da Motta Brandão, Política Econômica nos Anos de Chumbo (Rio de Janeiro: Editora Consequência; 2018).

2 Ver, entre outros, Guilherme da Costa Delgado, Capital financeiro e agricultura no Brasil (São Paulo: Ícone; Campinas: Editora da Unicamp, 1985); Guilherme da Costa Delgado, Do capital financeiro na agricultura à economia do agronegócio (Porto Alegre: Editora da UFRGS, 2012); Moacir Palmeira e Sérgio Pereira Leite, "Debates econômicos, processos sociais e lutas políticas”, em Luis Flávio de Carvalho Costa e Raimundo Nonato dos Santos (orgs.), Política e reforma agrária (Rio de Janeiro: Mauad, 1998).

3 Leonilde Servolo de Medeiros (org.), Conflitos e repressão no campo no estado do Rio de Janeiro (1946-1988) (Rio de Janeiro: Consequência, 2018). 
reflexão sobre esses anos, nos quais, ao mesmo tempo em que as lutas camponesas se articulavam e ganhavam visibilidade nos espaços públicos, trazendo para discussão temas como reforma agrária, direitos trabalhistas, direito de organização sindical dos trabalhadores do campo e violência, também se desenvolveu uma proposta articulada e consistente de intervenção no meio rural desenhada pelas instituições de representação patronal, em especial a Confederação Rural Brasileira (CRB) e a Sociedade Rural Brasileira (SRB). Referendado pelas articulações políticas em que essas organizações se envolveram, o projeto de mudança que elas propunham teve, como veremos, grande eficácia. Na sequência, analiso as medidas tomadas após o golpe, procurando mostrar como elas foram na direção das demandas por modernização da agricultura em detrimento de mudanças na estrutura fundiária, gerando um dinâmico e moderno empresariado rural ao mesmo tempo em que se reproduziam as práticas tradicionais de violência. A terceira e última parte se volta para as formas de ação empresarial na redemocratização e seus desdobramentos. Nela pontuo, a partir de experiência de pesquisa no estado do Rio de Janeiro, dificuldades relacionadas a fontes, abordagens e métodos e a limites não só para uma justiça de transição para os trabalhadores do campo, mas também para recuperar a memória de lutas e seu lugar na história recente do Brasil.

\section{Mobilização camponesa, empresariado rural e o debate sobre os rumos da agricultura brasileira nos anos que antecedem o golpe}

No Brasil, nos anos 1950/1960, consolidou-se o termo latifúndio como categoria política para nomear os grandes proprietários de terra. A generalização dessa denominação e seu crescente caráter político se deu em meio a um intenso debate sobre os rumos do desenvolvimento nacional, seus diferentes sentidos e alternativas que se esboçavam. Nesse debate, envolveram-se intelectuais, técnicos governamentais, deputados, senadores, mas também sindicatos operários, associações de trabalhadores rurais e entidades empresarias urbanas e rurais.

A partir da progressiva publicização dos conflitos no campo e do crescimento de demandas e da organização dos trabalhadores rurais, a palavra latifúndio passou a designar não só grandes propriedades marcadas pelo atraso tecnológico, mas também por relações de opressão, exploração, violência e de apropriação privada e ilegal de terras devolutas, prática conhecida como grilagem. ${ }^{4}$ No debate, aos latifundiários se contrapunham os camponeses,

4. Para esse debate ver Moacir Palmeira, "Os anos 60. Revisão crítica de um debate”, em Anais do Seminário Revisão crítica da produção sociológica voltada para a agricultura (São Paulo: Asesp e Cebrap, 1984); e Regina Reyes Novaes, De 
também categoria política, que nomeava os trabalhadores organizados, envolvidos em disputas por terra e em demandas por direitos trabalhistas. ${ }^{5}$ Os confrontos, tanto locais como nos espaços públicos, foram alimentados pelo surgimento, em diversos pontos do país, de associações de lavradores e ligas camponesas que explicitaram suas demandas, traduziram a luta por terra na linguagem da reforma agrária e, em áreas de monoculturas, com grande emprego de mão de obra, assumiram a linguagem dos direitos trabalhistas, até então legalmente reconhecidos só para os trabalhadores urbanos. Importante notar que essas demandas não se opunham entre si e era bastante comum que trabalhadores das grandes propriedades tivessem acesso a um pedaço de terra para cultivo de alimentos e criação de pequenos animais e combinassem luta por direitos trabalhistas ou regulamentação contratual (no caso de arrendamento) com a demanda por permanência na terra, assumindo a linguagem da reforma agrária e reivindicando também acesso à terra. ${ }^{6}$

São bastante conhecidas as demandas dos trabalhadores do campo e há diversos estudos que analisam as organizações que então surgiram. ${ }^{7}$ No entanto, há menos investimentos sobre os autodenominados produtores rurais que, já no início do século XX, começavam a se organizar. ${ }^{8}$ Suas entidades ganharam maior expressão nos anos 1950, mesmo momento em que se

corpo e alma. Catolicismo, classes sociais e conflitos no campo (Rio de Janeiro: Graphia, 1997).

5 Mário Grynszpan, Mobilização camponesa e competição política no estado do Rio de Janeiro: 1950-1964 (Dissertação de mestrado, Rio de Janeiro: Programa de Pósgraduação em Antropologia Social, Museu Nacional, UFRJ, 1987).

6 Leonilde Servolo de Medeiros, Lavradores, trabalhadores agrícolas, camponeses. Os comunistas e a constituição de classes no campo (Tese de doutorado, Campinas: IFCH/Unicamp, 1995).

7 Entre outros, ver Fernando Azevedo, As Ligas Camponesas (Rio de Janeiro: Paz e Terra, 1982); Elide Rugai Bastos, As Ligas Camponesas (Petrópolis: Vozes, 1984); Aspásia Alcântara de Camargo, “A questão agrária: crise de poder e reformas de base (1930-1964)”, em Boris Fausto (org.), História Geral da Civilização Brasileira. O Brasil Republicano, 3, t. III (São Paulo: Difel, 1981); Leonilde Servolo de Medeiros, História dos movimentos sociais no campo (Rio de Janeiro: Fase, 1989); Clifford Andrew Welch, A semente foi plantada (São Paulo: Expressão Popular, 2010).

8 Entre eles, destaco Benedita Maria Gomes Esteves, Confederação Rural Brasileira: origem e proposta (Dissertação de Mestrado, Rio de Janeiro: Programa de Pós-graduação em Desenvolvimento Agrícola, Universidade Federal Rural do Rio de Janeiro, 1991); Elisandra de Araújo Galvão, A política na CNA: organização, mobilizações e inserções do patronato rural no Estado (Tese de Doutorado, Rio de Janeiro: Programa de Pós-graduação em Ciências Sociais em Desenvolvimento, Agricultura e Sociedade, Universidade Federal Rural do Rio de Janeiro, 2020). Sobre os anos pós golpe, são pioneiros os estudos de Regina Bruno, largamente citados ao longo deste texto e de Sonia Mendonça, entre eles O patronato rural no Brasil recente (1964-1993) (Rio de Janeiro: Editora UFRJ, 2010). 
disseminavam as diversas organizações de trabalhadores e se contrapunham a elas. De alguma forma, a generalização da categoria latifúndio, utilizada, no debate político, como sinônimo de improdutividade e violência, acabou por produzir uma simplificação analítica desse segmento e dificultar a percepção de suas demandas e de sua capacidade de elaborar um consistente projeto modernizador, em especial no que se refere à dimensão tecnológica, e empresarial para a agricultura brasileira. Entre suas entidades associativas, ganharam destaque a SRB, fundada ainda em 1919, que reunia em especial cafeicultores de São Paulo e Paraná, e as federações de associações rurais de São Paulo, Minas Gerais e Rio Grande do Sul (Faresp, Faremg e Farsul), reconhecidas pelo Estado, e que estiveram à frente do processo que criou a CRB em $1951 .{ }^{9}$

Ao longo dos anos que antecederam o golpe, essas associações concentraram suas demandas em torno de três temas centrais: modernização da agricultura com apoio do Estado; combate sem tréguas à demanda por reforma agrária que ganhava corpo a partir das lutas camponesas e rejeição a qualquer forma de regulamentação das relações de trabalho no campo.

\section{Modernização da agricultura com apoio do Estado}

Já no início da década de 1950, eram constantes as reivindicações por uma política voltada para a modernização da agricultura. Analisando a situação do campo, a CRB e a SRB apontavam como os principais problemas enfrentados pelos produtores rurais a baixa produtividade da terra, como consequência, por um lado, de métodos de trabalho apontados por ela como rotineiros e ineficientes e, por outro, do esgotamento dos solos; a instabilidade da produção, resultado, ainda segundo essas associações, da ausência de crédito, armazenamento, transporte e de planejamento; o baixo rendimento econômico; o baixo nível de vida do homem rural, acarretando o êxodo quer de trabalhadores, quer de proprietários. ${ }^{10}$ A solução para os problemas agrários estaria, a partir desse diagnóstico, na melhoria das condições de vida no campo e dos métodos de trabalho na terra e comercialização dos produtos, de forma a assegurar justa remuneração às atividades rurais. O Estado teria um papel central nisso, por meio de políticas públicas, em especial crédito.

As demandas das associações se dirigiam principalmente à busca de condições que garantissem a rentabilidade da produção e se desdobravam em duas

9 As associações rurais foram regulamentadas pelo decreto-lei 7449 de 09 de abril de 1945. Tinham base municipal e, no decreto, era prevista a criação de uma entidade nacional. Distinguiam-se assim das associações de lavradores, não formalmente reconhecidas pelo Estado.

10 Gleba, 1955/12, p. 26. A Gleba era porta-voz da Confederação Rural Brasileira. 
dimensões: críticas ao imposto (chamado de confisco cambial) que gravava as exportações de café, principal produto da pauta de exportações do país e luta pela "racionalização" da produção, como condição para o aumento da produtividade agrícola. Justificando essas demandas, expunham também sua concepção sobre o crescimento da indústria. Para as entidades representativas dos empresários rurais, as indústrias que se desenvolviam no Brasil eram artificias e estavam sendo criadas pelo estímulo às emissões de papel moeda, provocando uma inflação que transformava a terra em objeto de especulação, desviando-a de sua "verdadeira função social”. O Estado era considerado o responsável pelo tratamento discriminatório contra a agricultura: "com os dólares do café importam-se indústrias obsoletas, cujos titulares enriquecem rapidamente". ${ }^{11}$ Frequentemente as entidades de representação patronais apontavam o paradoxo de o Brasil fabricar e exportar automóveis, ter indústrias pesadas e precisar importar feijão, carne etc. Assim, a política baseada na industrialização e a noção de desenvolvimento em que se ancorava contrariavam o que eles consideravam como sendo a “vocação agrária” do país e submetia os fazendeiros aos interesses industriais.

Lado a lado, estavam presentes reivindicações por melhoria das condições de produção na agricultura, envolvendo comercialização dos produtos; garantia de preços mínimos; crédito; facilidades para obtenção de tratores e implementos, veículos, adubos, inseticidas; transporte e armazenamento adequados; política agressiva de conquista de novos mercados para os produtos. A ausência dessas condições, segundo as associações rurais, explicava o êxodo rural, motivado "não apenas pelo baixo nível de renda da atividade agrícola, como também pela impossibilidade de competir com os salários da indústria”. ${ }^{12}$ A esse conjunto de fatores, as associações também ligavam as constantes crises de abastecimento que atingiam os centros urbanos, com alta de preços ao consumidor e falta de produtos básicos de alimentação. Para encaminhar esses temas, as sugestões eram a dinamização do Ministério da Agricultura; a reformulação do crédito agrícola, com a instituição de um Banco Rural; a criação de um Banco de Desenvolvimento Rural, para realizar grandes empreendimentos, como, por exemplo, obras de irrigação; mais recursos e agilização da Carteira de Crédito Agrícola e Industrial do Banco do Brasil; uso do cooperativismo como instrumento de fixação do homem à terra e "uma campanha de esclarecimento do capital estrangeiro, mostrando suas possibilidades de investimento na imigração e na colonização"; ${ }^{13}$ estímulo ao desenvolvimento da estrutura de armazenagem, ensilagem e transporte; garantia de preços mínimos;

11 A Rural, 469, 1960/05, p. 8. Esta revista era a publicação oficial da Sociedade Rural Brasileira.

12 Brasil Rural, 224, 1959/01.

$13 \quad$ A Gleba, 71, 1961, p. 16. 
intensificação da atuação do Serviço Social Rural, de forma a melhorar as condições de vida do trabalhador; estímulo à educação rural, enfatizando a formação profissional e as formas associativas, e às atividades de ensino, pesquisa e experimentação. ${ }^{14}$ Para tanto, reivindicavam o apoio do Estado.

Para essas demandas também convergiam pronunciamentos da Federação das Indústrias do Estado de São Paulo (Fiesp), principal entidade de representação empresarial do setor industrial, indicando que o divórcio entre agricultura e indústria, apontado pelo Partido Comunista Brasileiro, mas também pelas entidades patronais, era mais retórico que real.

\section{Reforma agrária}

As associações empresariais também falavam em reforma agrária, procurando impor sua versão dessa demanda que aparecia como principal bandeira das organizações camponesas e ganhava um número crescente de adeptos. A CRB argumentava que

o problema máximo a solucionar não reside na redistribuição das terras, mas: a) na melhoria das condições de vida do homem rural; b) na melhoria dos métodos de trabalho da terra; c) na melhoria dos métodos de comercialização dos produtos de forma a assegurar justa remuneração às atividades rurais. ${ }^{15}$

14 O Serviço Social Rural foi criado pela Lei $n^{\circ}$ 2.613, de 23 de setembro de 1955, como entidade autárquica, subordinada ao Ministério da Agricultura e constituída nos moldes do Serviço Social da Indústria (Sesi) e Serviço Social do Comércio (Sesc). Tinha por objetivo prestar serviços sociais no meio rural, melhorando as condições de vida da população; promovendo a aprendizagem e o aperfeiçoamento das técnicas de trabalho; fomentando a economia das pequenas propriedades e as atividades domésticas; incentivando a criação de comunidades cooperativas ou associações rurais; realizando estudos para o conhecimento e divulgação das necessidades sociais e econômicas do campo. A entidade operava sob controle da CRB: sua administração superior era exercida por um Conselho Nacional, integrado por um presidente, nomeado pelo presidente da República a partir de uma lista tríplice apresentada pela CRB, por um representante dos Ministérios da Agricultura, do Trabalho, da Educação, da Saúde (um por Ministério) e quatro representantes dos produtores rurais eleitos em assembleia da CRB. Foi extinto em 11 de outubro de 1962 pela Lei Delegada ${ }^{\circ} 11$, que criou a Superintendência da Política Agrária (Supra), sinalizando uma nova linha de atuação do governo federal na questão fundiária. Para maiores detalhes, ver http://www.fgv.br/cpdoc/acervo/dicionarios/verbete-tematico/servicosocial-rural, acesso em 02/02/2021.

15 Gleba, 1955/12, p. 27. 
Essa era a matriz das propostas que se fortaleceriam nos anos seguintes: a ênfase na necessidade de preparar o homem do campo como condição prévia para qualquer transformação de vulto no meio rural.

À medida em que as organizações camponesas se consolidavam e a reforma agrária começava a se configurar como exigência de um crescente e representativo movimento popular, ia também, no contraponto, tornando-se mais complexo o entendimento das associações patronais. Para elas, a reforma não era um problema de terras, mas sim de

dar assistência técnica e financeira ilimitadas e não condicionadas e restringidas por exigências de toda espécie, de forma a torná-las inoperantes. A reforma agrária nasce espontaneamente com a multiplicação dos balcões da Carteira Agrícola... Reforma Agrária se promove dando à atividade agrícola a segurança de que o empreendimento necessita. ${ }^{16}$

Para essas entidades de representação, era nas grandes fazendas que existia alguma assistência social (educativa, médica, dentária, religiosa ou recreativa) aos trabalhadores, tanto assalariados quanto pequenos proprietários de áreas vizinhas.

Também os empresários da indústria interviram nesse debate argumentando que

a Reforma Agrária não deve limitar-se à solução do problema da terra, mas envolver vasto programa de colonização, de difusão de modernas técnicas agronômicas, capazes de recuperar terras e explorá-las racionalmente; de educação e saúde para os homens do campo e sua família, de financiamentos e preços mínimos. ${ }^{17}$

Tratava-se fundamentalmente de coibir a propriedade improdutiva por meio de medidas tributárias e de estimular o cultivo da terra de forma a torná-la produtiva. Insistia-se também na necessidade de regularização dos arrendamentos, concedendo aos arrendatários as mesmas garantias contratuais de que gozavam os locatários urbanos.

Na mesma direção ia o Conselho Superior das Classes Produtoras, que congregava empresários rurais e industriais. Pesquisa feita por Fernando Henrique Cardoso, analisando a ideologia do empresariado industrial brasileiro, apontou que $90 \%$ dos grandes e $64 \%$ dos médios empresários consideravam a reforma agrária como solução inadequada para ampliar o mercado interno. Esse dado leva o autor a concluir que o conflito

${ }_{16}$ A Rural, 513, 1964/01, p. 6, grifos meus, LSM.

17 Desenvolvimento e Conjuntura, 1964/O5, p. 13-14. 
agroindustrial, embora presente entre essas frações, era secundário. ${ }^{18}$ Como veremos adiante, em que pesem divergências pontuais, empresários rurais e urbanos se juntavam na defesa da propriedade e na busca da modernização de suas atividades a partir do apoio do Estado.

\section{Legislação trabalhista}

Paralelamente, mas cruzando com o debate sobre a reforma agrária, desenvolvia-se um outro, sobre a extensão da legislação trabalhista ao campo. Embora desde os anos 1930 já fosse colocado como tema na esfera pública, o debate se acirrou após a aprovação da Consolidação das Leis do Trabalho, em 1943, e envolvia não só as entidades patronais então existentes, mas também os Ministérios da Agricultura e do Trabalho. ${ }^{19}$ Nos anos 1950, a proposta de extensão dos direitos trabalhistas ao campo foi retomada por meio de um projeto de lei, apresentado à Câmara dos Deputados. Num primeiro momento, as entidades empresariais rurais refutavam essa possibilidade, apontando-a como "impostura demagógica", e argumentavam que empregador e empregado estavam ligados por um mesmo destino e eram subordinados a outros setores que exploravam as atividades agrícolas como um todo. ${ }^{20}$

Argumentar contra a legislação trabalhista para os trabalhadores do campo significava também repudiar a associação dos trabalhadores em sindicatos. De um lado, os produtores rurais assinalavam a incapacidade do trabalhador rural para se sindicalizar em função de sua ignorância e dispersão espacial; de outro, acentuavam o caráter potencialmente perigoso dos sindicatos:

sendo o proletário rural brasileiro ainda imaturo para esse gênero de organização classista, nenhuma probabilidade de êxito ou vantagens poderá ele esperar de sua sindicalização. Muito mais provável, pelo contrário, é que sobre ele recaiam apenas despesas e obrigações de difícil cumprimento,

18 Fernando Henrique Cardoso, Política e Desenvolvimento em Sociedade Dependentes: ideologias do empresariado industrial argentino e brasileiro (Tese à Cadeira de Política, São Paulo: Ceupes, mimeo, FFCL/USP, 1969).

19 O tema é desenvolvido em Leonilde Servolo de Medeiros, Lavradores, trabalhadores agrícolas.

20 Desde os anos 1930 o tema da legislação trabalhista para os trabalhadores rurais era objeto de debate, mas se acirrou após a Consolidação das Leis do Trabalho, de 1943. O reconhecimento dos trabalhadores do campo como categoria profissional e, consequentemente, de seus direitos, só ocorreu com a aprovação do Estatuto do Trabalhador Rural (lei 4214 de 02 de março de 1963), que incorporou diversas cláusulas da CLT. Ver Sérgio Lamarão e Leonilde Medeiros, Estatuto do Trabalhador Rural (Verbete, CPDOC/FGV, http://www.fgv.br/cpdoc/acervo/dicionarios/verbete-tematico/estatuto-dotrabalhador-rural, acesso em 18/02/2021). 
enquanto os sindicatos oficialmente criados se transformam em veículos de ideias subversivas, de intrigas políticas, propícios à propaganda comunista. ${ }^{21}$

Ao argumento da imaturidade se somava o da necessidade de preservação da liberdade empresarial. A extensão da legislação trabalhista ao campo era considerada um verdadeiro atentado à liberdade tanto de propriedade quanto contratual, além de trazer o risco de "estabelecer a desordem nas fazendas". ${ }^{22}$

Nos momentos em que a regulamentação do trabalho rural parecia iminente, no entanto, o núcleo da discussão passou a ser a definição do próprio objeto das leis trabalhistas: o trabalhador rural, diferenciando contrato de trabalho e contrato de produção. Este último diria respeito a colonos, parceiros, empreiteiros, categorias que não eram consideradas como empregados, não sendo, pois, passíveis de serem recobertos pela legislação trabalhista. ${ }^{23}$ Além disso, procuravam enfatizar a ética do trabalho, afirmando que os mais dedicados e habilidosos conseguiam triunfar e que a miséria era resultante da falta de capacidade, tema que será recorrente nos anos posteriores. ${ }^{24}$

\section{A articulação empresarial: o Ibad e o Ipes}

Um salto organizativo dos setores empresariais brasileiros foi a criação do Instituto Brasileiros de Ação Democrática (Ibad), em 1959, e do Instituto de Pesquisa Econômicas e Sociais (Ipes), em 1961. Nessas instituições da sociedade civil, onde se organizava a elite orgânica do empresariado brasileiro e multinacional presente no país, o debate em torno da reforma agrária teve um papel de destaque. ${ }^{25}$ Suas teses a respeito foram registradas em dois livros marcantes na época. ${ }^{26}$ Segundo o Ibad, uma reforma democrática era a que visava dar a propriedade da terra ao maior número possível de pessoas “aptas” a cultivá-la e, assim, “difundir na massa rural aquelas qualidades de segurança, independência e responsabilidade que faltam às multidões passivas do interior e que caracterizam no mundo inteiro

21 A Rural, 494, 1962/06, p. 71.

22 A Rural, 435, 1957/06, p. 20.

23 Como já apontado, nas grandes monoculturas, os trabalhadores viviam no interior das propriedades, tinham acesso a pequenos lotes de terra para cultivo de alimentos, mediante regras costumeiras, dando margem à tese de que não eram "verdadeiros" assalariados.

24 É importante ressaltar que as qualificações de imaturo, ignorante, sem capacidade para o empreendedorismo tem sido uma constante nas discussões sobre a modernização e na justificativa do sucesso do agronegócio nos anos recentes.

25 René A. Dreifuss, 1964: a conquista do Estado (Petrópolis: Vozes, 1981).

26 IBAD, Recomendações sobre a reforma agrária (Rio de Janeiro: Ibad, 1961); IPES, Reforma agrária: problemas, bases e soluções (Rio de Janeiro: Ipes, 1964). 
a missão histórica da classe média rural”. ${ }^{27}$ A reforma agrária implicava em propiciar a "formação de empresários em condições de dirigir as propriedades, assim como a colocação da respectiva produção". ${ }^{28}$ A colonização deveria ser o instrumento da reforma agrária, com a terra sendo vendida aos que aspirassem a ela, embora a preços baixos e prazos longos de pagamento. Quanto à desapropriação, deveria ser feita com base no valor declarado para fins de tributação, com pagamento prévio em dinheiro e pelo preço justo.

O Ipes concordava com essas teses e defendia o apoio à transformação do latifúndio improdutivo em cooperativas de produtores, "comunidades de trabalho" ou em "empresas agrícolas em que os que trabalham a terra tenham relações com seus proprietários que se assemelhem às de um trabalhador industrial com os donos de empresa". ${ }^{29}$ Uma particularidade dessa entidade era a defesa da criação de uma justiça agrária, uma vez que, segundo os elaboradores da proposta, as tensões sociais existentes tinham sua origem no inadequado aparelhamento judiciário para solucionar de forma eficaz as questões ligadas ao uso da terra.

De acordo com Dreifuss, esses estudos deram as diretrizes para uma reforma agrária que favoreceria a transformação empresarial do campo, beneficiaria a burguesia rural moderna e os empreendimentos agroindustriais multinacionais e associados. Para isso, procuravam obter o apoio das oligarquias, por sua influência política no Congresso. Ao mesmo tempo, para os governantes,

os grandes proprietários de terra, significativa fonte de suporte financeiro, faziam-se também necessários na contenção dos camponeses e no apoio que davam às autoridades regionais, em particular aos governadores dos Estados que, por sua vez, opunham-se ao governo central..$^{30}$

Chamamos a atenção para a expressão "contenção dos camponeses", eufemismo para defender as relações de poder que vigoravam no interior das propriedades e que envolviam tanto controle via relações de favor, quanto a violência aberta, que ia de despejos a assassinatos de lideranças. O uso da força quando qualquer demanda aflorava era uma prática antiga, gerada ainda no escravismo, que ganhou fôlego com a crescente organização dos camponeses, mas que também passou a ter maior visibilidade, tornando-se questão pública e transformando a violência em tema discutido em diferentes arenas. ${ }^{31}$ Ana Carneiro e Marta Cioccari apresentam vários dados sobre essa

27 IBAD, Recomendações sobre..., p. 218.

28 IBAD, Recomendações sobre..., p. 194.

29 IPES, Reforma agrária, problemas..., p. 63.

30 Dreifuss, 1964: A conquista do Estado, 180-1.

31 Aproprio-me da noção de público de Daniel Cefaï, ver Daniel Cefaï, "Les cadres de l'action collective. Définitions et problèmes", em Daniel Cefaï, Danny Trom 
forma de ação que compreendia a invasão de sedes e intimidação de dirigentes dos recém-criados sindicatos: espancamentos, ameaças de morte, assassinatos de trabalhadores que reivindicavam direitos; impedimento de reuniões etc. ${ }^{32}$ Gregório Bezerra em suas memórias, quando narra seus esforços de organização dos trabalhadores do campo, também refere-se à forte vigilância nas fazendas, dificultando a entrada de estranhos e a realização de reuniões. ${ }^{33}$

Um dos casos mais emblemáticos dessas ações foi o assassinato, por pistoleiros, de João Pedro Teixeira, líder da Liga Camponesa de Sapé, na Paraíba. Nunca se chegou ao mandante, mas havia um reconhecimento geral de que fora um dos grandes proprietários da região. Da mesma forma, foi também assassinado José Mathias, líder das lutas dos posseiros da região de Pedra Lisa, na Baixada Fluminense, Rio de Janeiro. Há muitos outros casos não só de mortes, mas também de violências físicas, visando humilhar as lideranças emergentes, de prisões que provocaram inclusive amplas mobilizações, como é o caso da prisão de Jofre Correia, líder dos arrendatários que levaram adiante a chamada operação “arranca capim”, no interior paulista. $^{34}$

Essas ações são apenas alguns exemplos do que nos parece central na prática dos grandes proprietários ao longo do tempo: a violência aberta, por meio da ação de jagunços. As investigações eram escassas e nunca se chegava aos mandantes, cujos nomes, no entanto, circulavam na imprensa. Quando a polícia era chamada, regra geral, era para respaldar a ação do poder privado. Assim, as práticas cotidianas de violência e tentativas de impedir o avanço das organizações combinava-se com o discurso sobre a necessidade de modernização.

$\mathrm{Na}$ literatura corrente, pouco é dito sobre o protagonismo de grupos empresariais na disputa por terra, como é o caso dos usineiros em Pernambuco e Paraíba, como o mostram, por exemplo, as pesquisas de Regina Novaes e de Ana Carneiro e Marta Cioccari. No caso do Rio de Janeiro, destaca-se, por exemplo, em Nova Iguaçu, a presença dos Guinle,

(orgs.), Les formes de l'action collective. Mobilisations dans des arènes publiques (Paris: École des Hautes Études en Sciences Sociales, 2001).

32 Ana Carneiro e Marta Cioccari, Retrato da repressão política no campo. Brasil, 1962-1985. Camponeses torturados, mortos e desaparecidos (Brasília: Ministério do Desenvolvimento Agrário, 2a . ed., 2011).

33 Gregório Bezerra, Memórias. Ed ampliada e atualizada (São Paulo: Boitempo, 2011).

34 Welch, A semente foi plantada. Na região era costume que a terra fosse cedida em pequenos lotes a arrendatários que podiam plantar alimentos, mas deveriam deixá-la, após três anos, com capim plantado. Era uma forma de formar pastos sem custos para os proprietários. Na revolta citada, os arrendatários, em protesto, arrancaram o capim que haviam semeado. 
família proprietária da Companhia Docas de Santos e, em Cachoeiras de Macacu, da família Coimbra Bueno, com forte poder no estado de Goiás. ${ }^{35}$

\section{O golpe militar e o impulso para mudanças no campo}

Logo após o golpe e o afastamento do então Presidente da República, João Goulart, mandatos de deputados próximos às lutas populares foram cassados e governadores foram afastados, com a promessa de restabelecimento da ordem democrática assim que o "perigo comunista" fosse afastado.

No que se refere aos camponeses, a partir da pouca bibliografia existente, de registros que fizemos em pesquisa sobre o Rio de Janeiro e de notícias de imprensa de outros locais, a repressão começou de imediato, em especial nas áreas de conflito, com invasão de casas e revistas em seu interior, sob o pretexto de busca por lideranças e armas; intimidação das pessoas que nelas viviam, inclusive mulheres e crianças; destruição de lavouras; derrubadas de casas. Assim, disseminou-se o medo. Muitos silenciaram, outros até mesmo abandonaram seus locais de moradia e trabalho.

Se, em algumas áreas, os atos de violência foram levados adiante pelo Exército e pela Polícia, na maior parte do país, com o golpe, os proprietários de terra se sentiram liberados para agir segundo suas práticas tradicionais: as milícias privadas foram agentes centrais da violência que se instaurou no campo. ${ }^{36}$ Raras dessas ações foram documentadas, quer pela imprensa da época, quer por registros oficiais, mas o tema aparece em entrevistas com moradores dos locais onde ocorreram conflitos, inicialmente de maneira velada, mas, a partir do momento em que relações de confiança com os pesquisadores foram estabelecidas, de forma bastante detalhada. ${ }^{37}$

Mas o imediato pós-golpe não foi marcado apenas por ações repressivas. No que se refere ao campo, foram tomadas medidas visando regulamentar a questão fundiária com a nomeação de uma comissão para elaborar um Estatuto da Terra, legislação aprovada poucos meses após o golpe e fortemente inspirada na proposta, mencionada no item anterior, desenvolvida pelo Ipes. Essa lei contemplou algumas importantes demandas das

35 Reyes Novaes, De corpo e alma; Carneiro e Cioccari, Retratos da repressão; Medeiros, Conflitos e repressão.

36 Reyes Novaes, De corpo e alma. Situação bem próxima constatamos em pesquisa sobre o estado do Rio de Janeiro: Medeiros, Conflitos e repressão. Seria bastante produtiva uma revisita a toda a literatura sobre conflitos ocorridos no pré-64, mapeando os proprietários envolvidos e sua inserção econômica e familiar.

37 Entre os depoimentos que colhemos em pesquisa no Rio de Janeiro, um deles menciona o espancamento de uma liderança da região de Campos, que foi pendurada em uma árvore e espancado na frente da família. 
organzações empresariais e traduziu para termos legais categorias que faziam parte do discurso político na época, dando-lhe outro formato, mas, de alguma forma, reiterando sua relação com algo que deveria ser combatido em nome de um novo modelo de agricultura e de uma determinada concepção de desenvolvimento. ${ }^{38}$ De acordo com a nova lei, tanto o latifúndio quanto o minifúndio deveriam ser incentivados a se transformar em empresas, por meio estímulos produtivos ou aumento do valor do imposto territorial rural para propriedades ociosas. ${ }^{39}$ A empresa, que poderia inclusive ser uma propriedade de caráter familiar, tornava-se o modelo ideal de uso da terra: baseado numa administração racional (em termos do padrão produtivo que se desejava implementar), integrado a mercados e fundado em princípios de “justiça social”. Tratava-se também de incentivar a constituição de uma próspera classe média rural, entendida, tal como preconizado pelo Ipes e Ibad, como barreira à difusão das ideias "de esquerda” no campo. Para tanto, eram necessários mecanismos de indução para que, mesmo que propriedades de pequeno porte ou familiares, se transformassem em prósperas empresas.

A nova lei previa ainda a modernização das relações sociais e não só na dimensão tecnológica e produtiva. Segundo ela, a propriedade da terra deveria cumprir uma função social e o fazia integralmente quando, simultaneamente, favorecia o bem-estar do proprietário e dos que nela trabalhavam, assim como de suas famílias; mantinha níveis satisfatórios de produtividade; assegurava a conservação dos recursos naturais; observava as disposições legais que regulavam as justas relações de trabalho entre os que a possuíam e os que a cultivavam. ${ }^{40}$ Além disso, regulamentou os contratos de arrendamento e parceria, relações que haviam se tornado importante foco de conflito nos anos que precederam o golpe, trazendo para a lógica do contrato o que antes era regulado fundamentalmente pelo costume e pelas relações pessoais. ${ }^{41}$ Trata-se de inovações legais importantes que, inclusive,

38 Leonilde Servolo de Medeiros, Movimentos sociais, disputas políticas e reforma agrária de mercado no Brasil (Rio de Janeiro: Editora da UFRRJ e Unrisd, 2002).

39 Pela nova lei, os imóveis rurais foram classificados em minifúndios (propriedades com área inferior a um módulo e, portanto, incapazes, por definição, de prover a subsistência do produtor e de sua família); latifúndios por exploração (imóveis com área entre um e seiscentos módulos, mantidos inexplorados ou inadequadamente explorados em relação às possibilidades físicas, econômicas e sociais do meio em que se encontravam e/ou mantidos para fins especulativos); latifúndios por extensão (com área superior a 600 módulos, independentemente do tipo e características da produção nela desenvolvida) e empresas (imóveis entre um e 600 módulos, caracterizados por um nível de racionalidade na exploração compatível com os padrões regionais).

40 Por tal entenda-se o respeito à legislação trabalhista configurada no Estatuto do Trabalhador Rural, de 1963.

41 Medeiros, Movimentos sociais, disputas políticas. 
serviram de apoio para reivindicações de trabalhadores em luta por terra, como veremos adiante.

O Estatuto da Terra, ainda em seu momento de elaboração, despertou protestos das entidades empresariais rurais, em especial da SRB, que ameaçou "pegar em armas" contra o governo. A possibilidade de desapropriação nele contida foi a razão básica para o descontentamento. Tratava-se de negar qualquer possibilidade de intervenção governamental sobre o direito de propriedade, entendido como absoluto. Como veremos, nos anos seguintes, a política fundiária do governo militar voltou-se principalmente para ações de estímulo à modernização, cumprindo de perto as propostas das entidades patronais rurais, elaboradas nos anos que antecederam o regime empresarialmilitar. Desapropriações, limite de tamanho de propriedade e aplicação do imposto territorial rural progressivo como caminho para induzir a desconcentração fundiária foram deixadas de lado.

No entanto, logo após a aprovação da lei, algumas ações se seguiram, voltadas para áreas de conflito. Em determinadas situações, foram destinadas terras, por meio de mecanismos de compra, para abrigar camponeses provenientes de áreas de forte tensão. Caso exemplar é o do Rio de Janeiro, onde foram adquiridas algumas fazendas para assentar trabalhadores na principal área de conflito do estado, o município de Cachoeiras de Macacu. Para essas terras foram também levados lavradores de outras regiões conflagradas, inclusive onde ocorreram ocupações de terra. No entanto, é interessante observar que, nessa mesma área, uma fazenda vizinha, que havia que havia sido ocupada duas vezes e desapropriada no governo Goulart, foi devolvida aos antigos proprietários, um deles senador da República pelo Estado de Goiás. Em outras áreas também foram criados projetos de colonização como o Iguatemi (no atual estado de Mato Grosso do Sul), Alexandre de Gusmão (próximo ao Distrito Federal), Caxangá, em terras de uma usina e a Cooperativa Tiriri, ambos em Pernambuco. São raros os estudos sobre esses projetos, mas podese trabalhar com a hipótese de que essas ações, mesmo contrariando interesses locais, buscavam criar um clima de estabilidade para deslanchar políticas modernizadoras, intervindo pontualmente nos casos de conflitos mais intensos. Note-se que o termo usado para nominar esses projetos era “colonização”. O termo reforma agrária, também presente no Estatuto da Terra, foi deixado de lado nessas ações. ${ }^{42}$

Com base no Estatuto da Terra, foram criadas ainda as chamadas "comissões de regularização e fiscalização”, que tinham por função definir, nas áreas de

42 Mesmo assim, nos anos que se sucederam, foram decretadas algumas áreas “prioritárias para reforma agrária”. Se mapeadas, poderiam indicar a leitura que os militares e seus apoiadores faziam do que seriam as áreas dignas de intervenção e porquê. 
conflito, quem poderia ou não podia ficar na terra. No estado do Rio de Janeiro, essas comissões, chamadas de Guarda Rural, tiveram uma ação extremamente violenta contra os que eram posseiros ou os que haviam participado de ocupações, expulsando-os de seus lotes, queimando lenha que haviam colhido para venda e até mesmo destruindo suas casas. ${ }^{43}$ Possivelmente, ações semelhantes ocorreram em outros locais.

Em síntese, é importante ressaltar os vários níveis em que a violência se fez presente nas áreas rurais: um, mais visível, foi a perseguição e prisão de lideranças, intervenção em sindicatos e federações de trabalhadores e na própria Confederação Nacional dos Trabalhadores na Agricultura (Contag), entidade sindical, reconhecida em janeiro de 1964, que teve sua direção destituída e substituída por novos nomes, ligados ao trabalho de organização realizado pela Igreja Católica. Outra, muito pouco documentada, foi a ação repressiva dos militares, da polícia ou mesmo das milícias privadas nas áreas de conflito, não só sobre lideranças, mas também entre trabalhadores envolvidos em conflitos. Como já apontado, essas ações disseminaram o medo e provocaram um recuo organizativo e nas ações de resistência. ${ }^{44}$

\section{A modernização ganha corpo: novos empresários e velhas práticas}

Lado a lado com a repressão, iniciou-se uma política de forte estímulo à modernização do campo, que se fez em várias frentes, fortalecendo a dinâmica empresarial na agricultura, facilitando a modernização tecnológica das áreas de cultivos tradicionais, incentivando a agroindustrialização, criando condições privilegiadas para o acesso à terra por grandes grupos empresariais industriais e financeiros, em especial nas áreas de fronteira, estimulando projetos de colonização privados e a constituição de um mercado de terras. Tiveram papel importante nesse processo segmentos de origem camponesa, de origem sulina, que haviam se capitalizado ao longo dos anos 1950/1960, nos momentos iniciais do processo de modernização. Eram agricultores com experiência na agricultura modernizada do Sul que foram estimulados a migrar para as regiões Centro-Oeste e Norte, com o objetivo de levar para áreas de ocupação recente outro estilo de uso da terra. Essa valorização da

43 Fabrício Teló e Leonilde Servolo de Medeiros, "Violência e poder do Estado nos momentos iniciais do regime militar: a ação da Guarda Rural do IBRA", em Marcos Bretas, Luiz Edmundo de Moraes e Jean Rodrigues Sales, O testemunho como janela: movimentos sociais e repressão durante a ditadura militar no Brasil (Rio de Janeiro: Lamparina, 2019).

44 O livro já citado de Carneiro e Cioccari traz abundantes exemplos de situações de violência. Também o relatório da Comissão Camponesa da Verdade é uma importante fonte para se conhecer a amplitude e as dimensões da repressão. Ver Sérgio Sauer et al., (orgs.), Comissão Camponesa da Verdade. Relatório final: violações de direitos no campo. 1964 a 1988 (Brasília: Dex-UnB, 2016). 
experiência de agricultores marcados pela racionalidade empresarial alimentava o forte preconceito contra as populações locais e suas práticas agrícolas, consideradas atrasadas, estimulando divisões étnicas. Posseiros, ribeirinhos, povos indígenas eram por eles considerados pouco afeitos ao trabalho contumaz e à lógica dos ganhos monetários. Tratava-se aí de uma outra forma de violência, simbólica, que desqualifica o outro e não o reconhece. ${ }^{45}$

Nesse processo, função social da propriedade passou a ser identificada com produtividade, deixando de lado os elementos constitutivos, no corpo da lei, da sua definição, ou seja, tanto o respeito aos direitos trabalhistas quanto ao ambiente.

Ao longo desses anos, gestou-se uma profunda transformação no meio rural, base do que hoje é chamado de agronegócio. ${ }^{46}$ Para a viabilização de tais mudanças, foi essencial o apoio do Estado, que abraçou as propostas de segmentos empresariais rurais e também dos militares para ocupação das fronteiras, quer facilitando projetos agropecuários, quer de colonização, tanto públicos como privados.

O início da década de 1970, já no governo Médici, foi um marco de significativas mudanças, expressas na criação de instituições, que produziram uma reviravolta tanto na ocupação de áreas novas como no próprio desenho das políticas públicas para meio rural. É digno de nota o curto espaço em que ocorreram, o que explicita um projeto solidamente arquitetado. Entre essas medidas destacamos a criação do Plano de Integração Nacional, estabelecendo que cem quilômetros em cada lado das estradas a serem construídas na região Norte seriam destinadas à colonização, iniciando-se pela Transamazônica. O Instituto Brasileiro de Reforma Agrária (Ibra), bem como o Instituto Nacional de Desenvolvimento Agrário (Inda), órgãos previstos no Estatuto da Terra e destinados a promover a reforma agrária e o desenvolvimento agrícola, expressão comum na época para designar mudanças nas práticas "atrasadas", foram substituídos pelo Instituto Nacional de Colonização e Reforma Agrária (Incra), subordinado ao Ministério da Agricultura, portanto, vinculado a interesses setoriais. Em 1972, foi criada a Empresa Brasileira e Pesquisa Agropecuária (Embrapa), que se mostrou uma peça chave nas pesquisas agronômicas que permitiram a ocupação dos cerrados e, em 1974, a Empresa Brasileira de Assistência

45 Ver Axel Honneth, Luta por reconhecimento. A gramática moral dos conflitos sociais (São Paulo: Editora 34, 2003).

46 O termo agronegócio começa a ser usado no Brasil nos anos 1990, para designar não só os produtores modernizados, mas sua inserção em uma complexa cadeia de produção de insumos, processamento e comercialização/exportação por meio de grandes empresas. Substituiu e politizou o termo usado nos anos 1970/1980, cadeias agroindustriais. 
Técnica e Extensão Rural (Embrater), cujo principal objetivo era contribuir para a disseminação da chamada revolução verde.

O foco da questão fundiária voltou-se para a ocupação da região amazônica, em especial o norte de Mato Grosso, Pará, Rondônia, estados para onde foram levados agricultores do Nordeste num primeiro momento, mas, a partir dos anos 1970, principalmente do Sul do país, em projetos de colonização.

A colonização oficial, em terras públicas, se fez paralelamente à cessão de terras de áreas a empresas privadas ou mesmo cooperativas de produtores do sul do país. ${ }^{47}$ Um exemplo ilustrativo é a Sinop (Sociedade Imobiliária Noroeste do Paraná), que implantou, na pré-amazônia matogrossense, um projeto inicialmente com 480 mil hectares, mas que, com a agregação de novas terras, chegou a 645 mil, cortado pela BR 163 (Cuiabá-Santarém), então ainda em processo de abertura. ${ }^{48}$ Os lotes, com 60 hectares em média, foram vendidos a colonos do Sul. ${ }^{49}$ Em situações como esta, a empresa colonizadora acumulava a função de vendedora das terras, intermediária entre os colonos e o banco financiador e prestadora de serviços sociais.

Diversos pesquisadores chamaram a atenção para o fato de que essas colônias tinham por objetivo tanto expandir espaços de produção, quanto o controle do espaço amazônico. ${ }^{50}$ Mas eram também espaços para assentar populações originárias de áreas de conflitos em outros estados. É o caso, por exemplo, da Colônia Terranova, instalada numa área total de 435 mil hectares no município de Colíder, em Mato Grosso, no final da década de 1970, e destinada a abrigar famílias expulsas pelos indígenas Kaingang da sua reserva, no Rio Grande do Sul. Num outro caso, o Incra transferiu terras devolutas à Cooperativa Agropecuária Mista de Canarana (Coopercana), por meio de um financiamento do Banco do Brasil, via Programa de Redistribuição de Terras e de Estímulo à Agroindústria do Norte e Nordeste (Proterra).51 A garantia hipotecária era a própria terra. Foi também esse

47 Costa Delgado, Capital financeiro e agricultura.

48 A área deu origem ao município de Sinop, que se autonomizou de Chapada dos Guimarães em dezembro de 1979. Para maiores detalhes ver Edison Antonio Souza, "História de Sinop: Sociedade Imobiliária Noroeste do Paraná”, em João Carlos Barrozo (org.), Mato Grosso: do sonho à utopia da terra (Cuiabá: Editora da UFMT/Carlini e Caniato Editorial, 2008).

49 Colono é o termo que designa os descendentes de migrantes europeus que vieram principalmente para o sul do país ainda no século XIX e se tornaram proprietários de pequenos lotes de terra.

50 Souza, "História de Sinop".

51 Este Programa foi criado em 1971, com o objetivo de facilitar o acesso à terra para trabalhadores das áreas da Superintendências de Desenvolvimento da Amazônia (Sudam) e do Nordeste (Sudene) mediante indenização dos proprietários em dinheiro (e não em títulos, como previa o Estatuto da Terra). 
banco estatal que financiou a construção da infraestrutura do projeto. As parcelas foram vendidas aos colonos pelo valor estimado da terra nua, acrescentado dos custos das obras feitas diretamente na parcela (desflorestamento e habitação) e da proporção correspondente do custo da infraestrutura. Para arcar com esses pagamentos, o colono recebia um crédito, também pelo Banco do Brasil, que deveria ser saldado em 15 anos com carência de cinco e juros de $6 \%$ ao ano. Paralelamente, havia outro crédito do mesmo banco, intermediado pela Cooperativa, para investimento. Como mostra Tavares dos Santos, muitos desistiram, construindo a saga dos colonos retornados, uma das origens dos sem-terra, que marcaram, a partir dos anos 1980, a história das lutas por terra no sul do país. Mas outros foram bem sucedidos e se constituíram na base da nova onda de ocupação da região. ${ }^{52}$

Os dois exemplos que selecionamos indicam que a colonização atraiu públicos diferenciados, mas teve uma marca comum: foi possível graças à concessão de terras devolutas pelo Estado e vultosos financiamentos pelo Banco do Brasil, condição para o sucesso desses empreendimentos. Processos semelhantes ocorreram também no Pará ao longo da Transamazônica, fortalecendo um novo segmento de interesses fundiários: as empresas colonizadoras.

Uma série de outros casos, envolvendo grandes empresas, são narrados por Antônio Canuto, mostrando, por exemplo, a ação da Associação dos Empresários da Amazônia, que reclamava da "desproporção entre o número de índios e o tamanho da reserva, impossibilitando que os proprietários das áreas as explorassem". O mesmo autor menciona a venda de 800 mil hectares de uma área onde viviam índios Xavante, para a família Ometto, que detinha várias usinas de cana em São Paulo. ${ }^{53}$

No entanto, essas áreas de fronteira eram habitadas por povos indígenas e posseiros e a condição para ocupá-la e transformá-la em terra de negócio era a expropriação dessas populações. ${ }^{54}$ Foi um processo extremamente violento,

52 José Vicente Tavares dos Santos, Matuchos. Exclusão e luta. Do Sul para a Amazônia (Petrópolis: Vozes, 1993).

53 Antônio Canuto, Resistência e luta conquistam território no Araguaia mato-grossense (São Paulo: Outras Expressões, 2019), 27 e 85. Note-se que a Associação dos Empresários da Amazônia era, nessa época, presidida pelo empresário paulista João Carlos de Souza Meireles, que também foi vereador pela cidade de São Paulo. Ele, ainda segundo Canuto, também comandou a implantação da Frenova (Fazendas Reunidas Nova Amazônia S/A) abarcando sete fazendas num total de cerca de 400 mil hectares.

54 José de Souza Martins explora a diferença entre terra de trabalho e terra de negócio, expressões que foram incorporadas ao documento, aprovado na $18^{\mathrm{a}}$. Assembleia da Conferência Nacional dos Bispos do Brasil, denominado A Igreja e os problemas da terra. https:// pstrindade.files.wordpress.com/2015/01/cnbbdoc-17-igreja-e-problemas-da-terra.pdf, acesso em 01/02/2021. Sobre as 
levado adiante por jagunços ligados a grupos especializados em "limpar" a terra e legitimar títulos, marcados por ilegalidades. Trata-se de situações pouco documentadas e pouco foram exploradas em termos de pesquisa, mesmo durante os trabalhos da Comissão Nacional da Verdade. Nesse clima de violência, havia poucas possibilidades de resistência e as que ocorreram foram brutalmente reprimidas.

Também os cerrados foram objeto de projetos de colonização, como o indica o Programa de Assentamento Dirigido do Alto Paranaíba, com colonos japoneses, selecionados pela Cooperativa Agrícola de Cotia, utilizando 60 mil hectares, desapropriados pelo governo de Minas. ${ }^{55}$ Essa experiência foi o ponto de partida para a constituição, em 1975, do Programa para o Desenvolvimento do Cerrado (Polocentro) e do Programa Nipo-Brasileiro para o Desenvolvimento do Cerrado (Prodecer), que tinha por objetivos o desenvolvimento de uma agricultura "moderna e racional" no bioma.

Em qualquer das situações, tratava-se de incentivar um novo padrão agrícola, base do que hoje é conhecido por agronegócio. Não por acaso, trinta anos depois, os cerrados tornaram-se mares de soja (no caso do Triângulo Mineiro, café), plantada em especial por "gaúchos", termo usado para designar os empresários descendentes de colonos bem sucedidos de origem sulina, num processo de contínua expansão que atinge hoje o Oeste Baiano, Sul do Piauí e do Maranhão e norte do Tocantins (área conhecida pela sigla Matopiba).

A esse padrão de ocupação se somaram ainda os estímulos a empresas e empresários voltados para produção de gado de corte. Também nesse caso ocorreram intensos conflitos, dos quais são exemplos significativos os que aconteceram com a transformação dos seringais acreanos em pastagens e a resistência dos seringueiros que se seguiu. Essa resistência produziu importantes lideranças que foram assassinadas a mando de fazendeiros. É o caso de Wilson Pinheiro, morto em 1980, e Chico Mendes, em 1988.56

reflexões do autor a respeito, ver José de Souza Martins, “Terra de negócio e terra de trabalho: contribuição para o estudo da questão agrária no Brasil”, em José de Souza Martins, Expropriação e violência. A questão política no campo (São Paulo: Hucitec, 1980).

55 Hailton Pinheiro de Souza Jr., O lugar do progresso. Família, trabalho e sociabilidade em uma comunidade de produtores de café do cerrado mineiro (Rio de Janeiro: E-papers, 2011).

56 Wilson Pinheiro era expressiva liderança local. Chico Mendes ultrapassou as fronteiras nacionais quando conseguiu unir as bandeiras da preservação de modos de vida com as lutas ambientais. Ganhou dois prêmios internacionais (Global 500 da Organização das Nações Unidas e medalha do Meio Ambiente da Better World Society. Para maiores detalhes, ver Elder Andrade de Paula e Silvio Simione da Silva (orgs.), Trajetórias da luta camponesa na Amazônia acreana (Rio Branco: Editora da Universidade Federal do Acre, 2006). 
Como aponta Guilherme Delgado, o mercado de terras passou a ser central nesse processo. Os limites para concessão de terras sem autorização do Senado Federal (três mil hectares) viraram letra morta, assim como o tamanho máximo de 600 módulos rurais para as propriedades. ${ }^{57}$ Pelo contrário, as maiores unidades foram privilegiadas, estimulando a concentração fundiária nas áreas novas, onde se faziam concessões de terras e financiamentos também a grandes empresas do setor financeiro e industrial. Foi o caso da Volkswagen, Belgo-Mineira, Bradesco, Bamerindus, Varig, Tamakavi, Light, Klabin, Aracruz Celulose, entre outras, que obtiveram acesso a crédito com taxas baixas de juros, parcialmente empregado nas atividades rurais e parte dirigida ao fortalecimento das atividades de origem, fossem elas industriais, financeiros ou de serviços. ${ }^{58}$ Nesse contexto, a terra tornou-se um ativo, com o grande capital "operando especificamente nas instituições formais do mercado de terras - as imobiliárias e colonizadoras rurais; ou ainda diversificando suas aplicações patrimoniais, segundo estratégias variadas de valorização financeira nesse mercado". ${ }^{59}$

\section{Transformações nas relações de trabalho}

Até final da década de 1950, como já apontado, ainda predominava, nas fazendas produtoras de gêneros para exportação, um sistema em que os trabalhadores moravam no interior das propriedades, trabalhando parte do tempo nas lavouras comerciais, no reparo de instalações, recuperação de caminhos internos etc, mas também produzindo alimentos para si, com eventual venda de excedentes em mercados locais. A modernização mudou profundamente essa lógica. A mecanização do trato inicial da terra, por meio de uso de tratores cada vez mais potentes, a adubação química e a disseminação de herbicidas, dispensando o trabalho manual de limpeza de ervas daninhas, tornaram desnecessário manter muitos trabalhadores vivendo no interior da propriedade. Além disso, com a introdução da legislação trabalhista em 1963, colocava-se, pelo menos em tese, a necessidade de arcar com uma série de custos provenientes dos direitos

57 Os exemplos anteriores mostram a dimensão das terras apropriadas.

Considerando que na época o maior módulo rural era de 100 hectares (válido para grande parte da região amazônica), pelo Estatuto da Terra, uma propriedade poderia ter no máximo 60 mil hectares. Com mais que isso seria considerada latifúndio por dimensão, portanto passível de desapropriação. Esse cálculo simples mostra o quanto o Estatuto da Terra foi deixado de lado.

58 Costa Delgado, Capital financeiro e agricultura; José de Souza Martins, $A$ militarização da questão agrária no Brasil (Petrópolis: Vozes, 1984); Palmeira e Leite, "Debates econômicos".

59 Costa Delgado, Capital financeiro e agricultura, 55; José Francisco Graziano da Silva, Progresso técnico e relações de trabalho na agricultura (São Paulo: Hucitec, 1981). 
conquistados (salário mínimo, férias, décimo-terceiro salário, repouso remunerado, entre outros). ${ }^{60}$ Com isso, intensificou-se a expulsão dos trabalhadores do interior das fazendas, particularmente nas regiões produtoras de frutas, como é o caso dos laranjais paulistas; nos cafezais paulistas, paranaenses e mineiros e nas áreas de produção de cana-de-açúcar, em especial com a criação, em 1975, do Programa Nacional do Álcool, voltado ao incentivo à substituição de combustíveis derivados de petróleo por álcool.

Grande parte desses trabalhadores deslocou-se para as grandes cidades, em busca de trabalho, ampliando as periferias e a favelização e a especulação fundiária na franja urbana, com a transformação de áreas rurais em loteamentos, muitas vezes clandestinos. Com pouca ou nenhuma escolarização, restou-lhes trabalhos com baixa remuneração, como é o caso da construção civil, por exemplo. Muitos, no entanto, fixaram-se nas pequenas cidades interioranas na expectativa de contratos temporários em períodos de colheita: são os chamados "boias-frias", trabalho precarizado, sem acesso a direitos trabalhistas e marcados por uma forte exploração da sua força de trabalho. ${ }^{61}$

Deste momento datam também as primeiras denúncias sobre a presença da "peonagem" ou "trabalho escravo", utilizado em especial nas áreas de desmatamento da região amazônica. Trata-se de trabalhadores que, arregimentados por empreiteiros, eram levados para os lugares mais inóspitos, com suas despesas de locomoção e alimentação garantidas, mas descontadas no acerto final quando a tarefa terminasse. Nesse momento, o trabalhador pouco ou nada recebia, repondo um ciclo de infindável de dependência com os empreiteiros que agenciavam a venda de sua força de

60 Naquela conjuntura, os trabalhadores tinham poucas condições de se organizar para lutar pelo cumprimento dos direitos garantidos em lei desde 1963. Em algumas áreas houve recursos à Justiça, com encaminhamento individual e até mesmo coletivo de questões, mas os trabalhadores que recorriam a esse tipo de ação foram objeto de intensa repressão. Para melhor compreensão dessa situação, ver Moacir Palmeira, "Desmobilização e conflito: relações entre trabalhadores e patrões na agroindústria pernambucana”, em Bernardo Mançano Fernandes, Leonilde Servolo de Medeiros e Maria Ignez Paulilo (orgs.), Lutas camponesas contemporâneas: condições, dilemas e conquistas, vol. 1, O campesinato como sujeito político nas décadas de 1950 e 1960 (São Paulo: Editora da Unesp; Brasília: Nead, 2009), 171-200.

${ }_{61}$ Maria Conceição d'Incao e Mello, O boia-fria. Acumulação e miséria (Petrópolis: Vozes, 1975); Lygia Maria Sigaud, Os clandestinos e os direitos (São Paulo: Duas Cidades, 1978); Graziano da Silva, Progresso técnico; Verena Stolcke, Cafeicultura. Homens, mulheres e capital (1850-1980) (São Paulo: Brasiliense, 1986). 
trabalho. Forte vigilância e uso recorrente da violência em casos de rebeldia eram os traços marcantes dessa relação. ${ }^{62}$

\section{As formas da violência}

Num contexto em que, por um lado, havia censura sobre os meios de comunicação e, por outro, os interesses empresariais (do nascente agronegócio, das indústrias e do capital financeiro) se amalgamavam de forma inédita e se afirmavam como os construtores do desenvolvimento, pairava silêncio sobre as práticas que sustentavam essa expansão e que misturavam apropriação legal com grilagem, modernização com trabalho escravo e ações violentas contra qualquer forma de resistência. Chama a atenção o fato de que essas práticas não eram marca só dos produtores mais tradicionais, mas caracterizaram as empresas modernas do setor industrial e financeiro. Foram recorrentes as denúncias de trabalho escravo em propriedades que Bradesco, Volkswagen, entre outras, haviam obtido mediante incentivos governamentais na região amazônica. ${ }^{63}$

Nesse contexto, ganhou destaque o trabalho da Comissão Pastoral da Terra, criada em 1975, inicialmente atuando nas áreas da Amazônia Legal, mas rapidamente expandindo-se por diferentes pontos do país, na defesa de posseiros e dedicando-se a um intenso esforço organizativo. Ela procurou dar voz e denunciar a violência no campo e vários de seus integrantes foram ameaçados e mortos, não por acaso no período de redemocratização, quando as resistências no campo ganharam maior intensidade e visibilidade. Caso exemplar é o do padre Josimo Tavares, várias vezes ameaçado e assassinado em 1986, em razão da sua atuação em defesa de posseiros no Tocantins. ${ }^{64}$

Há muitas dificuldades, como já afirmamos, para documentar essas violências nos anos da ditadura, em razão da repressão, do medo que se instalou, das dificuldades de fazê-las chegar aos espaços públicos. No entanto, ao longo do período de redemocratização, pouco a pouco, por pressão de organizações da sociedade civil, foram sendo abertos arquivos que continham documentos que permitiram compreender as formas de ação do Estado brasileiro durante o regime militar. O acervo de Inquéritos Policiais Militares reunidos no projeto Brasil, nunca mais; a disponibilização dos arquivos dos Departamentos de

62 Ver, entre outros, Ricardo Rezende Figueira. Pisando fora da própria sombra (Rio de Janeiro: Civilização Brasileira, 2004) e o estudo pioneiro de Neide Esterci, Conflito no Araguaia. Peões e posseiros contra a grande empresa (Petrópolis: Vozes, 1987).

63 Ver Ricardo Rezende Figueira, "Por que o trabalho escravo?", Estudos Avançados, 14, 38 (2000): 31-50.

64. Ver Sauer et al., Comissão Camponesa da Verdade. 
Ordem Política e Social dos estados; o projeto Memórias Reveladas do Arquivo Nacional; e arquivos locais permitiram aos pesquisadores acesso a uma vasta documentação. No entanto, ela se relacionava em especial aos trabalhadores urbanos, militantes políticos e apoiadores (advogados, membros da Igreja, deputados) que, de alguma forma, passaram por prisões ou algum tipo de investigação formal, que provocaram a constituição de processos judiciais nos tribunais militares. ${ }^{65}$

No que se refere ao meio rural, como já indicado, o traço básico foi uma violência endêmica e difusa, marcada pela ação privada, por meio de jagunços, contra grupos de trabalhadores que, de alguma forma, questionavam as regras impostas pelos que se apossavam da terra e queriam expulsá-los. Para esses processos há pouca documentação: algumas denúncias; registros jornalísticos eventuais, em razão do contexto de censura à imprensa e também de adesão, em diversos casos, dos meios de comunicação à lógica da ditadura; registros sindicais (grande parte deles desorganizados e em mau estado de conservação); arquivos das comissões pastorais da terra locais, parte dos quais ainda pode ser recuperada da sede nacional da CPT. Como era de se esperar, nas publicações empresariais, há uma ênfase nas contribuições das ações dos empresários para "levar o desenvolvimento" a regiões onde o que havia era o "atraso" e um esforço constante de desqualificação dos habitantes das zonas rurais, marcadas, como já vimos, segundo eles, pela ignorância e pelo atraso.

Nossa experiência com uma pesquisa levada a efeito sobre o tema no estado do Rio de Janeiro, mostra que um importante caminho para obtenção de registros das formas de ação tanto do Estado como de milícias privadas são os relatos orais, obtidos por meio de entrevistas com afetados diretamente (cada vez mais difícil em razão do correr do tempo) e de suas famílias. Também os registros sindicais trazem, quando passíveis de consulta, detalhes das ações empresariais junto a comunidades de agricultores. Foi esse caminho que nos permitiu perceber as nuances da ação empresarial propriamente dita ou de acaparadores de terras, em grande parte dos casos, devolutas, que as "limpavam" e depois buscavam mecanismos legais para colocá-las no mercado. Nesse quadro, a ideia de reparação aos trabalhadores do campo torna-se cada vez mais distante.

No seu importante estudo sobre o tema, Gilney Viana identifica, com base em arquivos sindicais, da CPT, do MST e da Secretaria de Direitos Humanos da

65 Como mostra Anthony Pereira, na busca por mostrar que as instituições funcionavam e que o Brasil não era uma ditadura, houve julgamentos formais de muitos acusados de crimes de subversão. São esses julgamentos que constituem a base do acervo do Projeto Brasil Nunca Mais. Ver Anthony Pereira, Ditadura e repressão. O autoritarismo e o estado de direito no Brasil, no Chile e na Argentina (Rio de Janeiro: Paz e Terra, 2012). 
Presidência da República, 1196 casos de mortes e desaparecimentos forçados de camponeses ou de apoiadores de suas lutas, a grande maioria, como já apontado, pelas mãos de agentes privados. ${ }^{66} \mathrm{O}$ autor selecionou para estudo 602 casos. Entre eles, estão 131 casos de morte e ou desaparecimento forçado com ação de agentes do Estado e 471 pela atuação de agentes privados. Foram objeto desse tipo violência lideranças locais (463), sindicalistas (75), advogados que se envolveram na defesa de trabalhadores (14) e religiosos (7). Esses dados falam por si mesmos como caminho para entender a natureza da repressão nos locais de conflito.

Segundo o autor, apenas 51 requerimentos de reparação foram à Comissão de Mortos e Desaparecidos Políticos, criada em 1995, a maioria de militantes de esquerda e de lideranças. Os demais perderam o prazo e foram excluídos. Esses elementos mostram uma dificuldade central da Justiça de Transição no Brasil: chegar ao campo. Como já ressaltado, o medo, a dificuldade de informação e de acesso aos poderes públicos são fatores importantes para explicar esse silêncio. A necessidade de comprovação, de constituição de provas válidas judicialmente dificultam a constituição de processos e a formalização de denúncias. O tempo decorrido e a demora da instalação de uma Comissão da Verdade trouxeram dificuldades adicionais, porque as famílias muitas vezes são de difícil localização, saíram de suas áreas de moradia originais em busca de melhores condições de vida. ${ }^{67}$

Nos dados apresentados por Viana, chama a atenção o fato de que cerca de $70 \%$ dos casos estudados ocorreram entre 1979 e 1988, período da chamada transição democrática. Evidentemente isso se relaciona com o fato de que as lutas no campo se acirraram no período, com a multiplicação de acampamentos e ocupações e também das resistências de posseiros em especial nas áreas de expansão recente dos investimentos empresariais, como é o caso do Mato Grosso, Pará, Maranhão. Mas os números também indicam uma forte subestimação dos casos ocorridos ao longo dos anos 1970, quando eram enormes as dificuldades de registro. Para esse período como já apontado a melhor fonte disponível são os registros sindicais, que variam de local a local, em função do próprio envolvimento dos sindicalistas no acompanhamento e relato dos conflitos e ações de violência. A hipótese mais plausível é que muitos casos ficaram sem registro e dificilmente será possível recuperá-los.

66 Gilney Viana, Camponeses mortos e desaparecidos: excluídos da Justiça de Transição (Brasília: Secretaria de Direitos Humanos da Presidência da República, 2013).

67 A Comissão Nacional da Verdade do Brasil foi criada em 2011, mas só foi oficialmente instalada em maio de 2012. Entregou seu relatório final em dezembro de 2014. 


\section{Redemocratização e violência e os limites da justiça de transição, da disputa por memória e reparação nas áreas rurais}

Ao final dos anos 1970, estava clara uma nova configuração empresarial no meio rural que ainda merece ser mais estudada, em especial no que se refere à formação, nos cerrados, de uma nova burguesia agrária, cuja origem é um campesinato sulino bem sucedido, que levava para as novas regiões concepções empresariais de ocupação de espaço e de valorização do pioneirismo, colocando-se como desbravadores de áreas novas e portadores do progresso. Também reproduziam práticas discriminatórias em relação às populações locais, como indicado anteriormente. A emergência desse segmento se deu em paralelo à modernização das famílias tradicionais, controladoras de determinados espaços e do poder político local, como exemplificam as histórias das famílias Caiado em Goiás; Ometto, em São Paulo; Maranhão, em Pernambuco; Coutinho na Paraíba, entre outras.

As transformações das elites agrárias ao longo dos anos 1970 representou também rearranjos na representação do setor. Progressivamente organizações por produto ou multiproduto ganharam visibilidade em relação à tradicional organização sindical, a Confederação Nacional da Agricultura (CNA), criada em 1964 a partir da CRB. Temas relacionados à produção ocuparam a pauta dessas associações, assim como das modernas cooperativas empresariais que se constituíram naqueles anos e que apontavam para a emergência de novas formas de representação, baseadas em produtos e multiprodutos. ${ }^{68}$ Paralelamente, a CNA deixou de ser a principal porta-voz desses novos empresários.

Aparentemente, a modernização da agricultura triunfara e a discussão da questão agrária parecia obsoleta e fora de lugar. No entanto, no processo de redemocratização do país, no início dos anos 1980, era forte a pressão tanto por parte do sindicalismo rural, quanto do emergente Movimento dos Trabalhadores Rurais sem Terra (MST), para que o tema da reforma agrária compusesse o conjunto de bandeiras da Aliança Democrática. Eram também fortes as pressões contrárias, alimentando um debate que, nos termos em que era colocado, remetia ao início dos anos 1960. Nesse momento, um elemento novo foi incorporado ao repertório de ação dos trabalhadores do campo: as ocupações de terra, que revigoraram a luta por reforma agrária e lhe deram outro sentido. Não se tratava mais de defesa da permanência da terra onde se estava, mas sim da reivindicação por acesso a ela, por meio da ação direta, com ocupações das fazendas que eram apontadas como improdutivas. Embora ao longo dos anos 1970, a demanda por reforma agrária tivesse sido bastante expressiva na pauta dos sindicatos de trabalhadores rurais, ela agora ganhava

68 Sobre o tema, ver Regina Bruno, Um Brasil ambivalente. Agronegócio, ruralismo e relações de poder (Rio de Janeiro: Editora Mauad X, 2009). 
uma nova forma e a propriedade (improdutiva) era questionada diretamente por essas iniciativas que se constituíram em uma forma nova de pressionar e também de buscar diálogo com o Estado. ${ }^{69}$

Acampamentos e ocupações provocaram novos rearranjos em torno da luta por terra. Por um lado, a ênfase na ocupação de terras improdutivas e a adoção desse argumento como justificativa para as ações colocava no primeiro plano a ideia de produtividade, indicando o quanto esse termo, carregado de significados relacionados à revolução verde, penetrou profundamente como valor positivo na sociedade brasileira e acabou levando a que as próprias lutas por terra dos anos 1980 se dessem nos seus termos. ${ }^{70}$ Por outro lado, levou a que as forças patronais rurais se organizassem por outros canais em defesa da propriedade. Importante lembrar que as lutas de posseiros ganhavam cada vez maior expressão, bem como as dos povos indígenas, que iniciavam um processo de organização.

Particularmente revelador dessas tensões foi, já no início do primeiro governo civil, o anúncio, em maio de 1985, pelos representantes do Estado, num congresso da Confederação Nacional dos Trabalhadores da Agricultura, da proposta do $1^{\circ}$ Plano Nacional de Reforma Agrária, que fazia uma leitura desapropriacionista do Estatuto da Terra e levava ao extremo as potencialidades redistributivas desse instrumento legal, ainda vigente. ${ }^{71}$

Nos meses seguintes, evidenciou-se, em especial por parte dos proprietários de terra, uma forte reação à proposta. Um mês depois do Congresso da Contag, a partir de um grande acampamento de produtores rurais em Brasília, sob a liderança de Ronaldo Caiado, membro de família tradicional de proprietários de terra no estado de Goiás, criou-se uma associação empresarial que marcou o debate nos anos seguintes: a União Democrática Ruralista. ${ }^{72}$ Formada ainda em 1985, logo após o anúncio da proposta de I

69 Ver em especial Lygia Sigaud, “A forma acampamento: notas a partir da versão pernambucana”, Novos Estudos, 58 (2000): 73-92.

70 Ao longo da década de 1970, o sindicalismo rural se apoiou no Estatuto da Terra para apresentar suas demandas por desapropriação em áreas de conflito. Sem deixar isso explícito, a escolha do MST por acampar ou ocupar terras improdutivas mostra a importância de buscar fundamentos legais para suas ações.

71 Importante lembrar que na Nova República tornou-se presidente do Incra José Gomes da Silva, um dos elaboradores do Estatuto da Terra. Frustrado com a guinada dos governos militares em direção à modernização tecnológica sem reforma agrária, José Gomes fundou a Associação Brasileira de Reforma Agrária, aproximou-se do sindicalismo rural e tornou-se um defensor ardoroso dessa política, mostrando as potencialidades reformistas da lei que havia ajudado a criar.

72 Para maiores detalhes, ver Medeiros, Movimentos sociais, disputas políticas; Regina Bruno, "Nova República: a violência patronal rural como prática de classe", 
PNRA, e como resposta às ocupações, ela foi precedida pela criação de inúmeras associações locais que viram crescer rapidamente o número de seus associados. De acordo com Bruno, “a maioria dessas associações em defesa da propriedade contou com o suporte político e operacional dos sindicatos e federações patronais das regiões em que se constituíram, quando não eram os próprios presidentes dos sindicatos os coordenadores dessas iniciativas". ${ }^{73} \mathrm{Ou}$ seja, desenvolvia-se uma política de enfrentamento público, que transbordava o espaço tradicional dos conflitos localizados. Como aponta a autora, o que ela trouxe de novidade

foi seu alarde e justificativa [do uso da violência] num contexto histórico em que ela é condenada socialmente, usando o direito de propriedade privada existente no Código Civil para justificá-la... Em diversos pontos do país - em especial nas regiões de conflito de terra e onde os trabalhadores encontravam-se mais organizados - os fazendeiros preparavam-se para 'reagir a bala qualquer área que viesse a ser invadida' (Jornal do Brasil, $25 / 07 / 1985) \cdot{ }^{74}$

Organização de grupos de resistência e solidariedade, formação de milícias armadas para defesa da propriedade, críticas intensas às ações da Comissão Pastoral da Terra (ficou célebre, naquele momento, a frase/lema "para cada terra invadida, um padre morto”), realização de atividades de propaganda e legitimação por meio de leilões de gado, destinados também a financiar suas atividades, foram algumas das iniciativas da nova entidade. ${ }^{75}$

A essas práticas, associou-se a disputa por lugares do Congresso Nacional e a firme ação parlamentar. A Assembleia Nacional Constituinte (1987/1988) foi um dos palcos desses embates. Do ponto de vista da reforma agrária, o resultado foi a aprovação de um texto constitucional ambíguo. Por um lado, a reforma agrária passou a nele constar, bem como o princípio da função social da propriedade, atendida quando a propriedade rural cumpre, simultaneamente, os requisitos de aproveitamento racional e adequado; utilização adequada dos recursos naturais disponíveis e preservação do meio ambiente; observância das disposições que regulam as relações de trabalho; exploração que favoreça o bem-estar dos proprietários e dos trabalhadores (art. 186). No entanto, no artigo anterior (185), a Carta Magna afirma que a

Sociologias, 10 (2003): 154-189. Regina Bruno, Senhores da terra, senhores da guerra. A nova face política das elites agroindustriais no Brasil. (Rio de Janeiro: Forense Universitária e Editora da UFRRJ: 1997); Regina Bruno, "Um novo campo do conflito agrário. As associações patronais em defesa da propriedade e o movimento de ocupação de terra durante a Nova República”, em Bruno, Um Brasil ambivalente.

73 Bruno, Um Brasil ambivalente, 74.

74 Bruno, Senhores da terra, 82.

75 Bruno, Senhores da terra. 
propriedade produtiva não pode ser desapropriada. ${ }^{76} \mathrm{Ou}$ seja, foi introduzida uma tensão legal que, por um lado, tornou central o papel do Judiciário nas disputas por terra e, por outro, reforçou a concepção, que há muito vinha se firmando, de que o meio rural era antes de mais nada um espaço de produção e não de desenvolvimento de diversificados modos de vida. ${ }^{77}$

Se a década de 1980 foi marcada por lutas pela redemocratização e coroada pela aprovação de uma Constituição que garantia diversos direitos de cidadania, isso não significou que a violência cessou. Pelo contrário, o aparecimento da UDR é um indicador e, ao mesmo tempo, um estimulador dela. A chamada Nova República começou sinalizando a continuidade da repressão no campo e a força dos interesses empresariais ligados à propriedade da terra, mesmo que, agora, sob a face de uma agricultura moderna e pujante. Como mostra a pesquisa de Gilney Viana, é justamente nesse período que a violência no campo se acirra (ou consegue ser registrada). Mais uma vez fica evidente o que Florestan Fernandes tratou, ao longo de sua obra, como formas de entrelaçamento do atraso com o moderno, traço constitutivo da sociedade brasileira. ${ }^{78}$

Com efeito, a violência continuou sendo uma forte presença no meio rural. Não é possível, com os dados disponíveis, quantificá-la durante o regime empresarial-militar. Dados de arquivos da Contag mostram que ela foi uma constante em todos os estados do país e ganhou diferentes formas, tal como apontado ao longo deste artigo. A CPT, pouco a pouco, foi sistematizando dados e desenvolvendo uma sofisticada metodologia para isso, mas o primeiro informe sistemático a respeito é de 1985. A partir de então, todo ano, a

76 Ambos artigos foram regulamentados pela Lei 8629 de 24/02/1993, conhecida como Lei Agrária. Sobre os embates na Constituinte, ver, entre outros, Adriano Pilatti, A constituinte de 1987-1988: progressistas, conservadores, ordem econômica e regras do jogo (Rio de Janeiro: Editora da PUC/Rio; Lumen Juris, 2008).

77 Ver Maria de Nazareth Wanderley, O mundo rural como espaço de vida: reflexões sobre a propriedade da terra, agricultura familiar e ruralidade (Porto Algre: Editora da UFRGS, 2009). No entanto, é importante lembrar que foram reconhecidos os direitos dos povos indígenas às terras por eles ocupadas, bem como, nas disposições transitórias, a possibilidade de reconhecimento de terras originárias de quilombos. Esses ganhos legais indicavam sensível avanço do movimento indígena e do movimento negro e se desdobraram em demandas pelo reconhecimento de terras tradicionalmente ocupadas por outros grupos sociais. Para maiores detalhes, ver Alfredo Wagner Berno de Almeida, Terras de quilombo, terras indígenas, "babaçuais livres", "castanhais do povo", faxinais e fundos de pasto: terras tradicionalmente ocupadas (Manaus: PPGSCA-Ufam, 2006).

78 Aproprio-me aqui do sugestivo título de um texto de Regina Bruno. Ver Regina Bruno, "A atualidade de Florestan Fernandes. O entrelaçamento entre arcaico e moderno como traço constitutivo da sociedade brasileira”, em Bruno, Um Brasil ambivalente, e também Florestan Fernandes, A revolução burguesa no Brasil. Ensaio de interpretação sociológica (Rio de Janeiro: Zahar, 1981). 
entidade publica um boletim, intitulado Conflitos no Campo, onde os dados são publicizados. ${ }^{79}$ Nesse material chama a atenção a continuidade dos conflitos e das formas que a violência ainda hoje assume e que repetem as formas que marcaram o regime militar e os anos que o antecederam (despejos, ameaças de morte, assassinatos, uso de capangas, violações de direitos assegurados constitucionalmente, entre eles os trabalhistas e os que garantem a terra a povos indígenas e descendentes de quilombolas), indicando uma surpreendente permanência de práticas. Também chama a atenção o pouco empenho nas investigações e na identificação de mandantes. Quando muito são levados a julgamento os responsáveis diretos por crimes, os chamados pistoleiros ou jagunços.

Nos últimos anos se avançou, embora pouco, em termos de identificação da responsabilidade das empresas sobre ações de repressão. A recente condenação da Volkswagen abre um caminho importante..$^{80}$ No entanto, é muito difícil pensar em algo semelhante para as empresas que atuaram no campo, dada a dificuldade de recuperar testemunhos e principalmente pelo fato de que o que predominou foram ações de jagunços, eles também dotados de grande mobilidade e de difícil identificação.

Esse caminho nos leva a uma discussão sobre o processo de produção de memória, análise dos contextos dos depoimentos etc, que não temos como desenvolver aqui. Mas é um percurso indispensável para jogar luz sobre nuances da violência, a complexidade das alianças políticas locais e as formas cotidianas de resistência.

São elementos que ajudam a refletir sobre as complexidades do meio rural brasileiro. Por um lado, um vasto território, onde se desenvolvem relações regional e localmente diferenciadas. Falar em desenvolvimento capitalista não é suficiente para que possamos entender suas múltiplas formas e diversidade de relações criadas. Desse ponto de vista, é fundamental pesquisar os contextos específicos, as formas de repressão utilizadas pelas grandes empresas, mas também pelos fazendeiros, para buscar melhor compreender uma simbiose de práticas. É o caso, por exemplo, das denúncias

79 Esses cadernos estão disponibilizados na página de web da CPT

(www.cptnacional.org.br). Para um balanço das ações da CPT, ver CPT (org.),

CPT: 40 anos de fé, rebeldia e esperança (São Paulo: Expressão Popular, 2016);

Leonilde Servolo de Medeiros, “Conflitos fundiários e violência no campo”, em

Conflitos no Campo - Brasil, 2014 (Goiânia: CPT Nacional, 2014).

80 Em 2020, a Volkswagen foi instada a fazer um acordo com o Ministério Público Federal em São Paulo para reparar sua conduta durante a ditadura no Brasil.

Esse acordo implicou no encerramento de três inquéritos civis que tramitavam desde 2015 para investigar o assunto. Ver

https://g1.globo.com/carros/noticia/2020/09/23/volkswagen-faz-acordocom-mpf-para-reparar-violacoes-dos-direitos-humanos-durante-aditadura.ghtml, acesso em 20/04/2021. 
de utilização de relações de trabalho análogas à escravidão, inclusive por empresas consideradas modernas.

Ao longo dos anos, os processos de expropriação descritos neste artigo levaram a um abandono das áreas rurais, pela impossibilidade de nele se reproduzir, relacionada quer a processos de expropriação violentos, quer a formas mais sutis, vinculadas a processos econômicos: dificuldade da venda da produção, baixos preços, assistência médica e educacional inexistente ou precária.

Paralelamente, nos desdobramentos do processo que analisamos, verifica-se também uma forte ofensiva das entidades patronais na imprensa, nas articulações políticas, colocando-se como as agentes de progresso e, com isso, legitimando suas ações.

Dessa perspectiva, o que resta em termos de recuperação de memória e justiça é o esforço de não deixar essa história submersa e jogar luz sobre os atores, suas práticas. É garantir aos camponeses o direito de aparecerem como agentes dessa história que não se encerrou com o fim da ditadura. A violência no campo continua sendo uma constante, como mostram os boletins anuais da CPT. Ou seja, a democratização parece ainda demorar a chegar nas áreas rurais, mesmo passados mais de 30 anos do considerado marco maior da redemocratização no Brasil, que foi a Constituição de 1988. 
Title: Rural Entrepreneurs, Modernization of Agriculture and Violence in the Brazilian Rural Environment

Abstract: The article analyses how the rural policies of the Brazilian military government responded to some of the main demands of business sectors, organized in very active associations during the period before the coup. In its first part, the article shows the claims and the channels where they were made public. Then, it analyzes the military regime policies towards the rural sector, both in terms of repression and the making of rules and institutions that allowed a deep transformation during the 1970s. Finally, it shows how the repression was imposed, how the policies developed and how the violence continuity brought sensible obstacles to the possibilities of effective policies of transition justice.

Keywords: military-business dictatorship, peasants, rural business, agricultural modernization, violence

Título: Empresariado rural, modernización agrícola y violencia en las zonas rurales de Brasil

Resumen: El artículo analiza cómo el gobierno militar de Brasil, en sus políticas para el área rural, atendió algunas de las principales demandas de los sectores empresariales organizados en asociaciones que fueron bastante activas en el período anterior al golpe. En la primera parte, muestra cómo se constituyeron estas demandas y los canales a través de los cuales se hicieron públicas. A continuación, se analiza la política del régimen militar en relación con el campo, tanto en su dimensión represiva como en la constitución de leyes e instituciones que permitieron una profunda transformación modernizadora de la agricultura brasileña a lo largo de la década de 1970. En la última sección se muestra cómo el despliegue de las políticas de modernización, las formas en que se produjo la represión y la continuidad de la violencia en el campo suponen obstáculos importantes para las posibilidades de políticas efectivas de justicia transicional.

Palabras clave: dictadura militar-empresarial, campesinos, empresarios rurales, modernización agrícola, violencia 